ОСОБЛИВОСТІ ПІДГОТОВКИ МАЙБУТНІХ ТРЕНЕРІВ-ВИКЛАДАЧІВ СХІДНИХ ОДНОБОРСТВ ДО ПРОФЕСІЙНОЇ ДІЯЛЬНОСТІ В ДИТЯЧО-ЮНАЦЬКІЙ СПОРТИВНІЙ ШКОЛІ

\title{
PECULIARITIES OF PREPARATION OF FUTURE TEACHERS-TEACHERS OF EASTERN SINGLES FOR PROFESSIONAL ACTIVITIES
}

у статті проаналізовано сучасний стан підготовки майбутніх фрахівців фрізичної культури і спорту до використання східних одноборств у профресійній діяльності. Подано комплексний науковий аналіз проблеми підготовки майбутніх тренеріввикладачів східних одноборств до професійній діяльності в дитячо-юнацькій спортивній школі, який підтвердив актуальність і доцільність обраної проблеми, їі недостатню теоретичну розробленість у педагогічній теорії та практиці. На основі теоретичного аналізу психолого-педагогічної літератури і проведеного анкетування студентів вищих навчальних закладів України щодо з'ясування особливостей організації підготовки майбутнього тренера-викладача східних одноборств до просресійної діяльності в дитячо-юнацьких спортивних школах визначено, що сучасна підготовка майбутніх тренерів-викладачів східних одноборств все ще не відповідає вимогам, які мають враховуватися під час організації цього процесу. Залишаються нерозв'язаними питання забезпечення відповідності змісту $і$ способів організації навчальної діяльності студентів вищих навчальних закладів особливостям і тенденціям майбутньої професіійної діяльності згідно із сучасними соціально-економічними умовами країни. З'ясовано, що особливості підготовки майбутнього тренера-викладача східних одноборств до профеесійної діяльності в дитячо-юнацьких спортивних школах полягають у тому, що дана система повинна ґрунтуватися на комплексному підході до визначення й оновлення змісту, застосування методів, срорм і засобів навчання, що сприяє підвищенню есрективності означеного процесу. Розроблено й обгрунтовано зміст профресійної підготовки майбутніх тренерів-викладачів східних одноборств до профресійній діяльності у дитячо-юнацькій спортивній школі. Визначено доцільність використання $у$ професійній підготовці майбутніх тренерів-викладачів східних одноборств чотирьох груп методів: організації і здійснення навчально-пізнавальної діяльності студентів; стимулювання навчальної діяльності; контролю і самоконтролю навчання; фформування суспільної поведінки. Доведено, що практична підготовка повинна мати системний характер і складатися з таких етапів: лабораторні, практичні заняття; навчальна практика тренера-викладача, технологічна практика безпосередньо в організаціях, установах. Визначено, що перспективним напрямом розвитку профресійної підготовки майбутніх тренеріввикладачів східних одноборств є врахування інтересів особистості та ії підтримка у процесі розвитку. Це приведе до задоволення потреб фрізкультурної галузі у висококвалісрікованих тренерах-викладачах дитячо-юнацьких спортивних шкіл. Ключові слова: майбутній тренер-викладач, східні одноборства, дитячо-юнацька спортивна школа, спеціалізація.

The article analyzes the current state of preparation of future specialists of physical culture and sports for the use of oriental martial arts in professional activity. The complex scientific analysis of the problem of preparation of future coachesteachers of oriental martial arts for professional activity in children's and youth sports school is presented. On the basis of theoretical analysis of psycho-pedagogical literature and conducted questionnaire of students of higher educational establishments of Ukraine on finding out peculiarities of organization of preparation of future trainer-teacher of oriental martial arts for professional activity in children's and youth sports schools. It is determined that the modern training of future coaches-teachers of oriental martial arts still does not meet the requirements that must be taken into account when organizing this process. The questions of ensuring the content and ways of organizing the educational activity of students of higher education institutions to the peculiarities and tendencies of future professional activity in accordance with the current socio-economic conditions of the country remain unresolved. It has been found out that the peculiarities of preparation of the future coach of the oriental martial arts for professional activity in children and youth sports schools are that this system should be based on a comprehensive approach to the definition and updating of content, application of methods, forms and teaching aids. increasing the efficiency of the process. The content of professional training of future coaches-teachers of oriental martial arts for professional activity in children's and youth sports school is developed and substantiated. The expediency of using in the vocational training of future coaches-teachers of oriental martial arts of four groups of methods is determined: organization and realization of educational and cognitive activity of students; stimulation of educational activity; control and self-control of training; formation of social behavior. It is proved that practical training should be systematic and consist of the following stages: laboratory, practical classes; educational practice of a trainer-teacher, technological practice directly in organizations, institutions. It is determined that the perspective direction of the development of professional training of future coaches-teachers of oriental martial arts is taking into account the interests of the individual and its support in the development process. This will meet the needs of the physical education industry in high-quality coachesteachers of children's and youth sports schools. Key words: future trainer-teacher, oriental martial arts, children's and youth sports school, specialization. фізичного виховання і спорту

Запорізького державного університету 
Постановка проблеми в загальному вигляді. Соціально-економічні зміни в українському суспільстві, наміри України щодо інтеграції в європейську спільноту зумовили нові вимоги до професійної підготовки майбутніх фрахівців з вищою освітою. Вища освіта в Україні модернізується в напрямі її демократизації, гуманізації, розроблення перспективних моделей підготовки кваліфрікованих фрахівців відповідно до європейських стандартів. Однією зі складових частин вітчизняної фрізичної культури і спорту є східні одноборства, які почали відроджуватися в Україні і набули масового розвитку.

Виділення не вирішених раніше частин загальної проблеми. У сучасних умовах проблема ефективної підготовки майбутніх тренеріввикладачів до застосування східних одноборств у професійній діяльності не вирішується передусім через відсутність програм із підготовки фрахівців у вищих навчальних закладах, де розглядалися б не тільки особливості техніко-тактичної підготовки і спортивного тренування, а й історія, фрілософрія, етнічні закони східних видів спорту, їхня оздоровча спрямованість, особливості використання елементів цих видів спорту в навчальних закладах; відсутність спеціальної науково-методичної літератури.

Отже, наявні суперечності між значним зростанням кількості випускників фракультетів фрізичного виховання і їхньої неготовністю до застосування східних видів спорту у професійній діяльності (спортивна і фрізкультурно-оздоровча). Вирішення цієї проблеми потребує пошуку більш гнучких підходів до підвищення рівня профресійної підготовки майбутніх тренерів до роботи 3 дітьми шкільного віку з використанням східних видів спорту у професійній діяльності, переосмислення організаційно-методичних умов, мети, змісту, функцій і завдань профресійної підготовки у вищих навчальних закладах України відповідно до вимог сучасної парадигми освіти. Вихідні концептуальні засади підготовки майбутніх тренерів у вищих навчальних закладах, готових до використання східних видів спорту у профресійній діяльності, зазначені в законах України «Про освіту» (2002 р.), «Про фрізичну культуру і спорт» (1993р.).

Аналіз останніх досліджень і публікацій. Аналіз психолого-педагогічної літератури свідчить про значну увагу науковців до профресійної підготовки майбутніх тренерів до фрізичного виховання дітей шкільного віку.

Теоретичний аналіз засвідчив наявність великої кількості наукових праць, автори яких (Г.М. Арзютов, М.Я. Віленський, Л.О. Демінська, В.В. Кузін, В.С. Макєєва, Є.Н. Перфильєва, П.К. Петров, О.В. Петунін, Н.Є. Пфейфер, Л.П. Сущенко, О.В. Тимошенко, Ж.К. Холодов, В.Т. Чичикін, Б.М. Шиян, Ю.М. Шкребтій та ін.) приділили увагу дослідженню профресійних, структурних, особистісних, комунікативних, організаторських і гностич- них характеристик діяльності майбутніх фрахівців фрізичного виховання та спорту, спробували розробити найбільш оптимальні, ефективні комплексні методики для якісної підготовки майбутнього фрахівця фрізкультурного напряму у вищому навчальному закладі. Незважаючи на наявність досліджень, проблема підготовки майбутніх тренерів до застосування східних одноборств у професійній діяльності залишається актуальною.

Мета статті - з'ясувати особливості підготовки майбутнього тренера-викладача східних одноборств до професійної діяльності в дитячо-юнацьких спортивних школах.

Виклад основного матеріалу. Теоретичний аналіз базових понять дослідження щодо професійної підготовки майбутніх фрахівців із східних одноборств дозволив нам дійти висновку, що фрахівець зі східних одноборств має бути людиною, здатною до виконання педагогічної, психологічної, юридичної, геологічної, дослідницької, медичної діяльності, різноманітної змістовно-корисної діяльності, а саме: історико-краєзнавчої, патріотичної, оздоровчої тощо. Вивчення сучасного стану професійної підготовки майбутніх фрахівців зі східних одноборств підтвердило актуальність і доцільність проведення дослідження 3 обраної проблеми.

Підготовка і перепідготовка кадрів для східних одноборств традиційно була пов'язана 3 підвищенням кваліфікації фрахівців фрізичної культури та спорту, що, за відсутності базової освіти зі східних одноборств, не вирішувало кадрової проблеми підготовки таких спеціалістів. Вищі педагогічні навчальні заклади України були зорієнтовані на підготовку тільки кваліфікованих учителів фрізичного виховання і тренерів з олімпійських видів спорту. Опитування засвідчило, що 98\% респондентів-учасників Міжнародної конореренції зі східних одноборств уважають стан провадження східних одноборств у навчальних закладах незадовільним, і причиною цього, на їхню думку, є дефріцит фрахівців цього напряму роботи. Усі респонденти вважають за доцільне запровадження спеціалізації зі східних одноборств у вищих педагогічних навчальних закладах. Для розроблення концепції та моделі профресійної підготовки фрахівців зі східних одноборств здійснено історико-педагогічний аналіз розвитку східних одноборств на теренах України й аналіз закордонного досвіду підготовки спеціалістів цього напряму [2, с. 129].

Результати дослідження доводять, що східні одноборства на українських землях пройшли етапи розвитку, аналогічні європейським, тобто від поодиноких секцій до організації фредерацій із видів спорту [1, с. 34].

У результаті аналізу профресійної підготовки фрахівців східних одноборств у провідних країнах світу ми дійшли висновку, що найбільш вагомі 
ідеї щодо впровадження у профресійну підготовку фрахівців зі східних одноборств такі: широке використання інсрормаційних технологій; жорсткі критерії відбору абітурієнтів; ухвалення закону, що закріплює прийняття на роботу осіб із фраховою професійною освітою; доцільність фрункціонування суспільно-кваліфрікаційної структури кадрів і активу. Сформулюємо основні положення розробленої нами концепції профресійної підготовки майбутніх фрахівців із східних одноборств. По-перше, професійна підготовка майбутніх фахівців зі східних одноборств розглядається як цілісна система, що будується на основі органічної єдності загального, особливого й індивідуального. Профресійна підготовка майбутніх фрахівців зі східних одноборств, як загальне, є складовою частиною професійної підготовки майбутніх фрахівців із фрізичної культури і спорту; як особливе - має свою специфіку, зумовлену особливостями професійної підготовки майбутніх фрахівців зі східних одноборств; як індивідуальне - відображає залежність ефективності підготовки від особистісних якостей майбутнього фахівця, його психологічної культури, здатності до педагогічної та тренерської діяльності. Отже, особливості професійної підготовки майбутніх фрахівців із східних одноборств полягають у тому, що такий фрахівець має володіти професійними вміннями, які притаманні як тренеру з боротьби, так і викладачу-тренеру зі східних одноборств. По-друге, професійну підготовку майбутніх фахівців із східних одноборств доцільно здійснювати в системі професійної підготовки майбутніх спеціалістів фрізичної культури і спорту. Водночас принциповою специфрічною ознакою професійної підготовки майбутніх фрахівців із східних одноборств $€$ необхідність інтегративного підходу до формування ії змісту, відбору форм і методів, оскільки вона інтегрує в собі підготовку як фрахівців фрізичної культури і спорту, так і фрахівців східних одноборств. По-третє, у професійній підготовці майбутніх фрахівців із східних одноборств перевага має віддаватися діяльнісному підходу. Засобами реалізації професійних можливостей майбутніх фрахівців із східних одноборств у профресійній діяльності $€$ їхня фрізкультурно-педагогічна та тренерсько-викладацька діяльність. Особливість цієї підготовки полягає також у тому, що фрізичний розвиток студента, його спортивна і спеціальна підготовка здійснюються у нерозривній єдності і взаємозумовленості, що дало змогу ввести нову функцію профресійної діяльності майбутніх фрахівців із східних одноборств - національно-фрізкультурно-спортивну. Розроблена нами модель професійної підготовки фрахівців із східних одноборств відображає цілісний і неперервний процес професійної підготовки майбутніх фрахівців із східних одноборств, який відповідає освітньо-кваліфрікаційним рівням «бакалавр», «магістр».
Модель розкриває процес професійної підготовки майбутніх фахівців із східних одноборств відповідно до мети, завдань, принципів, відображає інтегративний підхід до професійної підготовки майбутніх фрахівців із східних одноборств, оскільки вона за змістом, формами і методами інтегрує в собі як підготовку фрахівців фрізичної культури та спорту, так і фахівців східних одноборств. Як видно з моделі, у змісті професійної підготовки майбутніх фрахівців фрізичної культури та спорту за освітньо-кваліфрікаційним рівнем «бакалавр фрізичної культури і спорту» виокремлено інваріантну і варіативну частини професійної підготовки. Інваріантна охоплює гуманітарні, соціально-економічні та фундаментальні дисципліни, які вивчаються згідно з навчальним планом підготовки тренера, з інтеграцією окремих тем зі східних одноборств. Варіативна частина включає професійно орієнтовані і вибірково-навчальні дисципліни, які вивчаються згідно 3 навчальним планом підготовки фрахівців фрізичної культури і спорту 3 інтеграцією профресійно спрямованих дисциплін із східних одноборств. На рівні бакалавра профресійна підготовка майбутніх фрахівців із східних одноборств спрямовується на поглиблення загальної освіти, формування фундаментальних і профресійно орієнтованих знань і вмінь, необхідних для вирішення типових професійних завдань, а також підготовку студентів до подальшого набуття спеціалізації «Східні одноборства». На рівні «магістр», згідно з моделлю, професійна підготовка майбутніх фрахівців із східних одноборств спрямовується на сприяння оволодінню студентами науковою та викладацькою діяльності у вищих навчальних закладах. У зв'язку із цим до блоку дисциплін освітньо-кваліфікаційного рівня «бакалавр» додаються такі дисципліни, як «Методи наукових досліджень у фрізичній культурі і спорті», «Фізичне виховання та тренерсько-викладацька робота у вищих навчальних закладах», «Основи лекторської майстерності». Після закінчення навчання магістри отримують кваліфрікацію «викладач вищого навчального закладу з фрізичної культури та спорту» і другу спеціальність - «тренер-викладач зі східних одноборств», що дає можливість як працювати в установах і закладах фрізичної культури і спорту, так і займатися педагогічною, науково-дослідницькою роботою в дитячоюнацьких школах та вищих навчальних закладах. Не менш важливою у психолого-педагогічній підготовці майбутніх фахівців із східних одноборств $€$ їхня готовність до реалізації «суб'єкт-суб'єктних» відносин у системах «тренер - спортсмен», що значною мірою залежить від особистісних якостей фрахівця із східних одноборств. Воночас особистісні якості тренера-викладача, на відміну від фрахівця фрізичної культури і спорту, зумовлені специорікою й особливостями цього виду діяльності. 
Вибір методів навчання пов'язується як 3 удосконаленням змісту підготовки, так і з розвитком пізнавальних здібностей студентів, їхнім особистісним удосконаленням. Визначено доцільність використання у професійній підготовці майбутніх фрахівців зі східних одноборств таких чотирьох груп методів: організації і здійснення навчально-пізнавальної діяльності студентів; стимулювання навчальної діяльності; контролю і самоконтролю навчання; формування суспільної поведінки. Доведено, що практична підготовка повинна мати системний характер і складатися з таких етапів: лабораторні, практичні заняття; навчальна практика тренеравикладача, технологічна практика безпосередньо в організаціях, установах. Класифріковано види практик - активна, дієва підготовка (виробнича) і практика професійного розвитку (переддипломна). Доведено, що важливу роль у практичній підготовці майбутнього фрахівця із східних одноборств має відігравати така фрорма навчання, як польові табори. Визначено й обґрунтовано їхній оптимальний обсяг. Ефективною формою організації навчального процесу також є дослідницька діяльність студентів, яка сприяє виробленню нестандартного підходу до виконання фахівцями зі східних одноборств своїх профресійних фрункцій. Зазначимо, що типовими видами діяльності випускників із вищою освітою (бакалаврів і магістрів) $€$ навчальна, спортивна, спортивно-оздоровча, духовна, виховна й організаційна робота. Саме це дає змогу майбутнім фахівцям зі східних одноборств працювати в дитячо-юнацьких спортивних школах та інших позашкільних закладах, фрізкультурних і спортивних організаціях, у системі Збройних сил України. Не викликає сумніву, що діяльність викладача має спрямовуватися на створення організаційно-методичних умов професійної підготовки майбутніх фрахівців із східних одноборств та включати стимулювання і мотивацію студентів до навчання; відбір змісту, фрорм і методів навчання студентів; організацію практич- них занять; стажування; упровадження інноваційних педагогічних технологій, контрольно-оцінну складову частину, самовдосконалення, розроблення навчально-матеріального забезпечення. Саме тому у процесі дослідно-експериментальної перевірки нашої моделі ми використовували критерії як ефрективності діяльності, так і професійної підготовленості майбутніх фахівців до спортивнооздоровчої діяльності. Під час дослідження нами розроблено і впроваджено: навчальний план підготовки фрахівців фрізичної культури і спорту із спеціалізацією «східні одноборства»; навчальні плани та робочі програми 3 усіх спеціальних дисциплін спеціалізації.

Висновки. Визначено, що перспективним напрямом розвитку профресійної підготовки майбутніх тренерів-викладачів із східних одноборств у вищих педагогічних університетах $€$ покращення якості їхньої професійної підготовки з урахування інтересів особистості, її підтримка у процесі розвитку, що приведе до задоволення потреб нашої країни у висококваліфрікованих конкурентоспроможних фрахівцях зі східних одноборств. Однак проведене дослідження не вичерпує всіх проблем профресійної підготовки майбутніх фрахівців із східних одноборств у вищих педагогічних навчальних закладах України.

Перспективи подальших досліджень у даному напрямі. Подальшої дослідної розробки потребують проблеми теоретико-методологічного обґрунтування педагогіки і психології східних одноборств; маркетингових досліджень потреби країни у кваліфрікованих фрахівцях зі східних одноборств.

\section{ББЛІОГРАФІЧНИЙ СПИСОК:}

1. Карпюк Р.П. Професійна підготовка майбутніх фрахівців з адаптивного фрізичного виховання: теорія та методика : наукова монографрія. Луцьк : ВАТ «Волинська обласна друкарня», 2008. 504 с.

2. Сисоєва С.О. Основи педагогічної творчості : підручник. Київ : Міленіум, 2006. 344 с. 